\title{
When (im)perfective is perfect (and when it is not)*
}

\author{
Olga Borik \\ Universidad Nacional de Educación a Distancia (UNED) \\ oborik@flog.uned.es
}

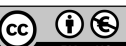

Received: January 26, 2018

Accepted: April 21, 2018

\begin{abstract}
The goal of this paper is to discuss some meaning correspondences (and/or clashes) between the perfective/imperfective aspectual contrast in Russian and various interpretations of a perfect in English. While a detailed comparison between perfect and (im)perfective, even in only two specific languages, is a project that clearly extends beyond all imaginable page limits for a single paper, I hope to demonstrate here some tendencies which might facilitate further (and deeper) theoretical and empirical studies of these two highly debated grammatical categories. In particular, the paper will show that there is a clear split between perfective and imperfective aspect in the non-past tense with respect to expressing perfect meanings and there is also a split between different existential meanings of the perfect in the sense that some of them correspond to the perfective aspect and some of them are only rendered by the imperfective aspect in Russian. Given this empirical picture, one of the theoretical questions that emerges from this study is what kind of repercussions the observed generalizations might have for a (universal) grammatical theory of tense and aspect.
\end{abstract}

Keywords: perfect; perfective; aspect; Russian; English

Resum. Quan l'(im)perfectiu és perfet (i quan no ho és)

L'objectiu d'aquest article és el de tractar algunes correspondències semàntiques (i/o divergències) entre el contrast aspectual perfectiu/imperfectiu en rus i les diferents interpretacions del perfet en anglès. Tot i que una comparació detallada entre el perfet i l'(im)perfectiu, encara que sigui només en dues llengües en concret, és un projecte que clarament s'estén més enllà de totes les pàgines límit imaginables per un únic article, espero demostrar aquí algunes tendències que poden conduir a la realització de més estudis teòrics i empírics (i més profunds) d'aquestes dues categories gramaticals tan debatudes. En particular, l'article demostra que hi ha una clara divisió entre l'aspecte perfectiu i imperfectiu en els temps de no-passat en referència a l'expressió dels significats del perfet $i$ hi ha també una divisió entre els valors existencials del perfet en el sentit que alguns d'ells es corresponen amb l'aspecte perfectiu i alguns d'altres només es realitzen amb

* I am extremely grateful to the editors of this volume, José M. Brucart and Teresa M. Xiqués, both for their kind invitation to participate in this volume and for their endless patience during the whole time that it took to put this volume together. I thank the two reviewers of this paper for their time and effort to read the paper and for their helpful comments. All the remaining errors are of course my own. The research presented in this paper was supported by the Spanish MICINN (grant FFI2014-52015-P). 
l'aspecte imperfectiu en rus. Considerant aquest marc empíric, una de les qüestions teòriques que sorgeix és quin tipus de repercussions poden tenir les generalitzacions que s'observen en aquest treball en la teoria gramatical del temps i l'aspecte.

Paraules clau: perfet; perfectiu; aspecte; rus; anglès
Table of Contents
1. Introduction
4. Perfect and its subtypes
2. Tense and aspect in Russian: some
5. Conclusion
brief reminders
References
3. Some Russian - English
correspondences

\section{Introduction}

This paper stems from what seems to be a common assumption in the literature (at least by now), namely, that perfect/non-perfect (as in English) and perfective/ imperfective (as in Russian) are two different grammatical and semantic oppositions (cf. Comrie 1976). Descriptively, the categories of (im)perfective and perfect can be characterized as follows (Comrie 1976: 12):

The term 'perfective' contrasts with 'imperfective', and denotes a situation viewed in its entirety, without regard to internal temporal constituency; the term 'perfect' refers to a past situation which has present relevance, for instance the present result of a past event.

This is a pre-theoretical description that nevertheless provides a basic intuition of what kind of grammatical meaning lies behind these two categories. But if it is clear that perfect and perfective are two distinct semantic categories, why look for any meaning correspondences between them at all? Do we have any evidence that such correspondences can in principle be found and that we might end up with a theoretically interesting descriptive generalization?

It is not entirely accidental that the terms perfect and perfective share the same stem, which is originally derived from Medieval Latin perfectivus, derived in turn from the Latin perfect-, past participle stem of perficere 'to finish, complete'. The intuitive connection between the two semantic categories can be formulated along the following lines: since (present) perfect relates a result of an event in the past to the present, the event itself is likely to be (a) completed and (b) seen as an integral whole 'from outside', which is exactly the descriptive characterization of perfective. ${ }^{1}$ It is worth emphasizing that this is only an intuitive connection, as absolutely nothing prevents perfect from combining with a situation viewed 'from within', which is a typical meaning of imperfective or progressive. English clearly

1. Clearly, this characterization only applies to the 'simple' perfect and not to the perfect continuous. 
exemplifies this possibility by having perfect continuous forms in its repository of tense/aspect forms.

A more substantial link between the semantic categories of perfect and perfective emerges from various work on Russian past passive participles and periphrastic passive constructions: it is widely assumed that at least a present passive (with the null auxiliary verb in Russian) conveys a perfect meaning (cf. Šaxmatov 1925/1941 and recently Schoorlemmer 1995; Knyazev 2007), as evident from the translation of the following example:

(1) Prestupnik zaderžan.

criminal detain.PST.PRT.PF

'The criminal has been detained.'

If this generalization is correct, the link between perfect and perfective becomes more perceptible: it is traditionally assumed that past passive participles, and hence periphrastic passives can only be formed from perfective verbs, ${ }^{2}$ which, according to the generalization, would express a perfect meaning in the passive construction.

Another potential link between perfect and perfective can be identified via resultativity (cf. Nedjalkov 1983): some analyses (e.g., Kamp \& Reyle 1993) relate the meaning of perfect, at least in English, to resultativity, while in the Russian linguistic tradition perfective and resultative meanings can be seen as related, mostly due to their relation to telicity. Moreover, diachronic studies convincingly show that there is a grammatical relation between resultative, perfect and perfective in many languages (cf. Bybee et al. 1994).

Finally, some theoretical approaches at least implicitly suggest that there is a connection between perfect and perfective. In Klein's (1994) version of the theory of temporal reference, there are two temporal relations that play a crucial role in establishing an overall temporal interpretation of a sentence. One is the relation between the topic time (TT) and the time of utterance (TU). In the more traditional and still very common terminology introduced by Reichenbach (1947), TT corresponds to the Reference time, with an important proviso: Klein's temporal variables are intervals, whereas Reinchenbach originally defined them as time points. The TT-TU relation is the one that determines the tense of a clause and provides a past, present or future interpretation. Another type of relation in Klein's model is the one established between the TT and the time of situation (TSit), which is the one referred to as aspect (Klein 1994: 6). Both perfect and perfective are seen as instantiations of this aspectual relation, ${ }^{3}$ hence the natural question is whether these two categories overlap in the possible range of meanings that they express. An answer to this question, to the best of my knowledge, has not been much contemplated in the recent literature on aspect, with a clear exception of Paslawska \& von Stechow's (2003) work, which explicitly addresses the issue.

2. But see Borik \& Gehrke (to appear) for challenges to this claim.

3. In addition to these temporal relations, Klein distinguishes three different situation types (0-state, 1-state and 2-state predicates), which of course increases combinatorial possibilities when TSit and TT come into play. 
On the other hand, there is another theoretical option that emerges from the semantic literature on the perfect, where a so-called extended now or XN-theory (McCoard 1978; Dowty 1979) has gained much popularity. The theory essentially consists in postulating a special temporal interval, called the perfect time span (PTS, see Iatridou et al. 2001), for a representation of the perfect. This interval is temporally related to the reference time of the clause and is located by its boundaries. The right boundary of the PTS is determined by tense. Thus, for present perfect, the right boundary of the PTS coincides with the speech/utterance time, for past perfect, it coincides with the reference time located prior to the speech time. The left boundary of the PTS can either be specified by adverbials (e.g., since 1995 locates the left boundary of the PTS in 1995) or left unspecified.

Note that since the XN-theory (or the PTS-theory) introduces an extra temporal interval into the semantic representation, it logically distinguishes between a viewpoint aspect (of which (im)perfective in Russian is assumed to be an example) and a perfect. According to Pancheva (2003: 285), the following temporal relations hold between temporal variables in a sentence:

(2) Tense: a reference time to the speech time

Perfect: a reference time to a reference time

Viewpoint aspect: the event time to a reference time

The PTS-theory seems to make different predictions with respect to perfect (im)perfective correspondences. Since viewpoint aspect and perfect are represented as two distinct semantic operators (and two distinct functional projections in syntax), there is nothing, in principle, that prevents perfect meanings from combining with both perfective and imperfective semantics. ${ }^{4}$

The empirical data from Russian that will be discussed in this paper seem to support a PTS theory of perfect, which predicts various combinations of perfect and viewpoint aspect. Modern Russian does not have a perfect construction per se (i.e., it does not have a perfect form), although there was such a form in Old Russian (see the discussion in section 3.3), therefore, from a synchronic perspective, we can only see how perfect meanings are expressed in Russian, and as I will show in the rest of the paper, the perfect meanings are definitely rendered by both perfective and imperfective aspectual forms, which is a clear indication of the two categories being independent. Nevertheless, there are various restrictions as well. After showing what the restrictions actually are, I will discuss their repercussions for theoretical accounts of aspect and tense.

Instead of following a usual theory-driven path, this paper focuses primarily on the empirical data. Theoretical discussions will be kept at an informal level. This is done on purpose: more often than not a chosen theoretical model predetermines what kind of data are taken into account. However, I do believe that taking

4. A clear counterexample to this claim seems to be provided by Modern Greek, where perfect structures are only formed from morphologically perfective verbs. See Iatridou et al. (2001), Moser (2003) for theoretical accounts. 
a reverse perspective and departing from purely empirical observations provides advantages that theoretically oriented approaches often miss. In particular, if our point of departure is a theory-independent description, we are more likely to discover solid and reliable empirical generalizations, which can be taken as a secure basis for developing a theoretical analysis. Moreover, an empirical perspective also allows us to evaluate the degree of adequacy that various theories can achieve in modelling the same empirical phenomenon. In this paper, I will (informally) discuss what are the theoretical approaches that seem to be better equipped for handling the observed meaning correspondences between the (im)perfective in Russian, on the one hand, and the perfect in English.

Having made these introductory remarks, I will now turn to the empirical focus of this paper, which is a comparison of uses of perfect in English and (im)perfective in Russian. The next section will provide a very brief description of the relevant parts of the grammatical system of Russian, just to remind the reader of the most important facts. Section 3 will be devoted to an overview of the (im)perfective/perfect correspondences and section 4 will discuss how different types of perfect relate to perfective or imperfective aspect in Russian. Section 5 concludes the paper.

\section{Tense and aspect in Russian: some brief reminders}

This section provides a very brief overview of some aspects of the system of aspect and tense in Russian. The basic facts, especially aspectual morphology, are widely described in the aspectual literature hence I will only repeat the most important facts and generalizations. Typical morphological processes that lead to aspectual value shifts, possibly among other meaning shifts, are prefixation and suffixation. The table 1 gives a very general overview of these processes.

This table illustrates how rich and complex the morphological system really is: we can find morphologically simple imperfectives (e.g., delat' 'to make, to do') but also perfectives (e.g., kupit' 'to buy'), morphologically complex imperfectives derived from a perfective (e.g., nakaplivat' 'to save') or from an imperfective base

Table 1. (Some) aspectual morphology in Russian'

\begin{tabular}{cccl}
\hline $\begin{array}{c}\text { Morphologically } \\
\text { imperfective }\end{array}$ & $\begin{array}{c}\text { Morphologically } \\
\text { perfective }\end{array}$ & $\begin{array}{c}\text { Morphologically } \\
\text { secondary (derived) } \\
\text { imperfective }\end{array}$ & Translation \\
\hline delat' & s-delat' & del-yva-t' & to make, to do \\
kopit' & na-kopit' & nakapl-iva-t' & to save \\
čitat' & pro-čitat' & $\begin{array}{l}\text { pročit-yva-t' } \\
\text { čit-yva-t' }\end{array}$ & to read \\
prygat' & pryg-nu-t' & ----- & to jump \\
kupit' & po-kup-a-t' & to buy \\
\hline
\end{tabular}

I. As for lexical meaning, all examples given in this table either have the same meaning for all corresponding aspectual forms in the same row, or exemplify predictable meaning shifts (e.g., prygnut' means 'to jump once/make a jump'). This, however, is not always the case, as is well known. 
(e.g, delyvat' 'to make, to do'), perfectives derived by prefixation (procitat' 'to read') or by suffixation (prygnut' 'to jump'), etc.

Table 1 illustrates that aspectual differences become apparent due to the morphological processes such as prefixation and suffixation. However, it also illustrates that there is no single perfective or imperfective morpheme in Russian, or, in other words, no uniform morphological aspectual marker. Nevertheless, there is still a somewhat misguided belief that the semantic opposition of perfective/imperfective in Russian and in other Slavic languages is morphologically marked. In this paper, I follow Klein (1995) who is rather explicit about the fact that there is no such thing as a morphological marker of aspect in general or of a particular aspectual value in Russian. So even though there is a substantial overlap between certain morphological processes such as, for instance, prefixation, on the one hand, and morphological perfectivity, on the other, there is no strict dependency between the two.

Another point that I would like to emphasize is that we should clearly distinguish between morphology, on the one hand, and the semantic values of perfective and imperfective aspect, on the other, even though it is often taken for granted that a morphologically perfective form (for instance, a prefixed verb) is necessarily also semantically perfective and the other way around. The distinction between morphological and semantic aspect is made explicitly by, for instance, Paslawska \& von Stechow (2003), Grønn (2003), Tatevosov (2015), and is assumed in this paper as well.

There are at least two clear cases that demonstrate the discrepancy between morphology and semantics in the aspectual domain. For instance, morphologically imperfective verbs in Russian are often used in a so-called 'general factual' meaning, discussed at length in Padučeva (1996), Grønn (2003: chapter 4), among many others. In this case, an imperfective verb refers to a single completed event in the past and the corresponding sentence asserts the mere fact that the event has taken place. As shown by Grønn (ibid.), this use can, in principle, be classified as semantically perfective. The following example illustrates the general factual use of the imperfective aspect in Russian:

(3) Knigu Strugackix ja emu uže daril, ne xočetsja book.ACC Strugackie.GEN I him already present.IPF.PRES not wish.REFL povtorjat'sja. repeat.REFL

'I have already given him a book by Strugackie as a present, I wouldn't like to do it again.'

Another context where morphology and semantics do not go hand in hand is provided by passive sentences: periphrastic passives in Russian normally express a resultative meaning (Schoorlemmer 1995) but imperfective participles can still be used in this construction (cf. Borik \& Gehrke, to appear). Again, this is a use of an imperfective verb form (a participial form, in this case) which should be classified as semantically perfective: 
Table 2. Tense forms in Modern Russian

\begin{tabular}{lll}
\hline & \multicolumn{1}{c}{ Imperfective } & \multicolumn{1}{c}{ Perfective } \\
\hline \multirow{2}{*}{ Past } & čita- $l$ & pročita-l \\
& read.IPF-PST.SG.MASC & read.PF-PST.SG.MASC \\
\hline \multirow{3}{*}{ Non-past } & čita-et & \\
& read.IPF-3SG & pročita-et \\
& bud-et čitat' & read.PF-3sG \\
& be-3SG read-IPF.INF & \\
\hline
\end{tabular}

(4) Znamenityj pokojnik nesen byl do mogily na rukax. Famous deceased.NOM carry.PST.PRT.IPF was until grave on arms 'The famous deceased was carried in arms until the grave.'

These and several other contexts show quite convincingly that there is no oneto-one correspondence between aspectual morphology and aspectual semantics. In this paper, I will be primarily concerned with (im)perfective forms expressing perfect meanings.

As for the tense system, I adopt the claim that there is one main opposition in the domain of tense in Modern Russian: past vs. non-past (Vinogradov 1947). There are five tense-aspect forms in Russian in total, three forms in the imperfective and two forms in the perfective. The asymmetry is due to the analytical imperfective future, formed by means of the auxiliary byt' 'to be' and an imperfective infinitive. The full system of tenses is presented in Table 2.

Past and non-past tense forms will be discussed in the next section where it will be shown that, independently of aspect, both perfective and imperfective forms in the past tense can have interpretations corresponding to various English perfect forms (cf. Forsyth 1970; Paslawska \& von Stechow 2003), while in the non-past tense there is a clear distinction between perfective forms, which can express perfect meanings, and imperfective forms, which, as the data suggest, cannot.

\section{Some Russian - English correspondences}

In this section, it will be shown that the principle of maintaining perfect and (im)perfective categories as two separate levels of temporal organization is, in principle, well supported by empirical data if you look at the past tense forms in Russian. As I will illustrate in section 3.1, all perfective and imperfective past forms can have perfect readings and a particular interpretation of a given sentence is usually determined by the context. Non-past forms, however, seem to show a clear tendency to attribute a (future) perfect interpretation only to perfective forms, whereas imperfective forms are used exclusively for progressive perfects (across all tenses). At the end of the section I will suggest a possible explanation for this asymmetry, keeping the discussion in rather informal terms. I will not develop a fully detailed, formal theoretical account in this paper. 


\subsection{Past forms with perfect meanings}

It is a well known fact that a Russian sentence with a past perfective verb can have different interpretations and can be translated into English by using different verb forms (see detailed descriptions in Forsyth 1970; Comrie 1976; etc.). Consider the following example:

(5) My kupili dom.

we buy.PF.PST house.ACC

(a) 'We bought a house.'

(b) 'We have bought a house.'

(c) 'We had bought a house.'

The translation in (5a), with a simple past tense, is a 'default' one. This is a translation that is usually offered for isolated sentences when the context does not provide any indications that a different verb form in English would be a more appropriate choice. But given the right context, both (5b) and (5c) can be suitable or even required translations. For instance, $(5 \mathrm{~b})$ is a perfect answer to a question like 'So what are you celebrating?' and (5c) is an accurate translation in a discourse like 'We didn't have savings anymore because we had bought a house.' In both contexts the Russian sentence in (5) would be absolutely correct to use.

The range of possible translations for (5) led some researchers to believe that semantically, perfective aspect in Russian has a stricter relation to perfect than had otherwise been assumed. Schoorlemmer (1995), for instance, argues that past passive participles formed from perfective verbs in Russian exhibit what she calls a 'perfect' effect. This means that a perfective participle essentially has a temporal structure of a perfect. Paslawska \& von Stechow (2003), in a detailed discussion of Schoorlemmer's work, propose that semantically, morphologically perfective active verb forms are not uniform and cover two semantic relations: a perfect one and a perfective one. However, as stated in more traditional descriptive literature (e.g., Forsyth 1970), not only sentences with perfective but also with imperfective verb forms can correspond to various perfect forms in English, as will also be illustrated below. Therefore, Paslawska \& von Stechow's (2003) conclusion was that both perfective and imperfective verbal morphology in Russian licenses perfect semantics. ${ }^{5}$

Turning now to the imperfective aspect, let me start by pointing out that, just like in the case of a past perfective, a sentence with a past imperfective verb can be translated into English by using various verb forms. The set of translations for (6)

5. The only form, as they state, that is not compatible with perfect semantics is the periphrastic imperfective future formed by means of the auxiliary byt' (to be) and an imperfective infinitive. A default translation for this form will be simple future in English (but crucially, not future perfective):

(i) My budem myt' posudu.

we will.1PL wash dishes.ACC

'I will wash the dishes/I will be washing the dishes.'

I will discuss non-past forms in section 3.2. 
is larger than the set of translations for $(5),{ }^{6}$ but both a present and a past perfect option is present in both sets and hence perfect meanings can be rendered by both past perfectives and past imperfectives.

(6) Ja guljal.

I walk.IPF.PST

(a) 'I was walking (when something happened).'

(b) 'I used to walk (every day).'

(c) 'I walked.'

(d) 'I have walked (already/today).'

(e) 'I had walked.'

Just like in the case of perfective verbs, an appropriate translation is mostly imposed by the context in which a sentence is used. Some examples of (immediate, sentential) context forcing one or another interpretation are given already in the translations. The present perfect translation in (6d) would be appropriate to use if the speaker stresses the fact that walking has already taken place and there would be no need to have another walk, for instance (as would be in the case of a recovering patient who needs fresh air). In addition to the range of possible correspondences illustrated in (6) above, it is not difficult to find examples where past imperfective is translated as a past perfect in English. For instance, the following one (Forsyth 1970: 81):

(7) K nam priezžal otec, no vskore uexal.

to us come.IPF.PST father but soon leave.PF.PST

'Father had come to see us but he went away again soon.'

This example illustrates the use of the imperfective aspect known as 'two-way action' (Forsyth 1970) or 'annulled result' (Smith 1991/1997), where the cancellation of the result of the event described by the verb is implied. ${ }^{7}$ In the example above, the cancellation is explicit: the imperfective priezžal means 'came and went away' and the second verb in the sentence explicitly asserts the going away event.

To sum up the discussion so far, it seems that the empirical facts strongly favour the hypothesis that perfect and (im)perfective are two independent semantic categories which can be freely combined since verbal forms of both aspects in the past tense in Russian can express present or past perfect meanings.

Note, however, that the aspectual restrictions come from other types of meanings that can be expressed by various aspectual forms in Russian. One meaning that can be rendered only by the imperfective aspect, in all tenses and irrespective of any other sentential or contextual factors, is a progressive/process interpre-

6. The reason for this is that two typically 'imperfective' meanings are added in the case of (6): a progressive and a habitual one ((6a) and (6b), correspondingly).

7. Altshuler (2013: 45-46) shows that this sentence entails that the arrival necessarily culminated, which is indeed a necessary condition for the result of the event to be cancelled. 
tation, which perfective verbs cannot express, ${ }^{8}$ as illustrated by the following examples:

(8) a. Kogda pozvonila mama, Petja pročital knigu when call.PF.PST mom, Peter read.PF.PST book 'When mom called, Peter had read a book.'

b. Kogda pozvonila mama, Petja čital knigu when call.PF.PST mom, Peter read.IPF.PST book 'When mom called, Peter was reading a book.'

With respect to perfect constructions, this generalization means that if a perfect continuous form is used in English, the corresponding Russian predicate will always feature an imperfective form in a corresponding tense.

In addition, when the English perfect is used to refer to a habitual/repeated situation, Russian will also use only imperfective forms to express this meaning (see Comrie 1976: 63, also for a version of the example below):

(9) Starye metody uže ne raz opravdyvali sebja.

old methods already not once justify.PST.IMP themselves

'The old methods have already on many occasions justified themselves.'

These two generalizations are very robust and both a progressive and a habitual reading have always been considered the most 'representative' or basic meanings of the imperfective aspect in Russian. In what follows, we will only consider sentences with an episodic non-progressive interpretation, to get a clear view on the relation between perfect and (im)perfective without any additional overriding factors. ${ }^{9}$ Let me now discuss non-past forms and as we will see in the following section, the empirical picture in the non-past domain differs considerably from the past one discussed in this section.

\subsection{Non-past forms with a perfect meaning}

Starting again with the perfective aspect, it can be easily shown that, among other meanings, the non-past forms can render future perfect interpretations. Consider the example below:

(10) Ja skažu emu pravdu.

I tell.PF.PRES him truth

(a) 'I will tell him the truth.'

(b) 'I will have told him the truth.'

8. Borik (2006) proposes a theoretical account for the aspectual system of Russian that directly builds on this generalization.

9. Although these overriding factors will eventually have to be taken into account as well. 
The translation options are more limited for non-past forms, and (10b) is definitely a marked, less natural interpretation of (10). Typically it is brought out by

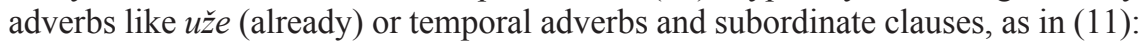

(11) K večeru/ Poka ty edeš, ja (uže) napišu statju. towards evening/while you go.IMP.PRES I (already) write.PRES.PF article 'By the evening/While you are on your way, I will have (already) written the article.'

Thus, as is exemplified by (11), non-past perfective forms can be successfully used to express a future perfect meaning.

As for present imperfective forms, the correspondences with perfect meanings are much more difficult to see or find, especially compared to past imperfective forms. It seems that at least for episodic actions present imperfective verb forms cannot express a (future) perfect meaning, as can be illustrated by (12):

(12) a. Jura napišet otčet $\mathrm{k}$ sledujusčemu ponedel'niku. Yura write.PF.PRES report towards following Monday 'By next Monday, Yura will have written the report.'

b. Jura pišet otčet $\mathrm{k}$ sledujusčemu ponedel'niku. Yura write.IPF.PRES report towards following Monday 'Yura is writing the report for next Monday.'

The difference in the interpretation of (12a) vs. (12b) is strikingly clear: while (12a) can (although does not have to) express a future perfect reading, (12b) can only mean that at present Jura is busy writing a document that will be needed next Monday. It seems impossible to conceive of a situation or a context that would allow (12b) to express a future perfect meaning.

Note, however, that due to the exclusive use of imperfective forms to express a process/progressive meaning, as has been already explained above, all the present perfect progressive forms will be rendered by present imperfectives in Russian, as illustrated in (13):

(13) My (uže) tri dnja krasim dom.

we (already) three days paint.IPF.PRES house

'We have been painting the house for three days (already).'

The meaning illustrated in (13) is a typical example of an extended now (XN) meaning, which as has been noted many times in the literature, is rendered mostly (although not exclusively, as will be shown in section 4) by the imperfective aspect in Russian (cf. Forsyth 1970, Comrie 1976, Paslawska \& von Stechow 2003, among many others).

The results of the empirical survey presented in this section can be summarized in the following table. The continuous forms in English are not taken into account in this table. 
Table 3. Correspondences between perfect in English and (im)perfective in Russian

\begin{tabular}{llccc}
\hline & $\begin{array}{c}\text { English past } \\
\text { perfect }\end{array}$ & $\begin{array}{c}\text { English present } \\
\text { perfect }\end{array}$ & $\begin{array}{c}\text { English future } \\
\text { perfect }\end{array}$ \\
\hline $\begin{array}{l}\text { Russian past } \\
\text { tense forms }\end{array}$ & perfective & $\checkmark$ & $\checkmark$ & - \\
\hline $\begin{array}{l}\text { Russian non-past } \\
\text { tense forms }\end{array}$ & perfective & $\checkmark$ & $\checkmark$ & - \\
\hline
\end{tabular}

As can be seen in this table, while the picture is completely symmetrical for the past forms and both aspects can express both past and present perfect meanings, there is an aspect split in the non-past forms and the future perfect seems to be rendered by imperfective aspect. In the next section I will suggest a tentative explanation for this phenomenon.

\subsection{The past vs. non-past asymmetry}

The idea that I want to informally present in this section is the following. The fact that there is an 'aspectual' split in the possibility to express perfect meanings in the non-past forms in Russian but no such split is observed in the past forms can be explained by postulating that tense morphology in Russian past vs. non-past forms does not express the same type of temporal relations. Partially this idea was already presented and developed in Borik (2006), although a possible difference between past and non-past forms was not considered there.

Let me first present the relevant empirical facts. Morphologically, the past tense in Modern Russian is expressed by means of the suffix $-l$, as was shown in Table $2 .{ }^{10}$ This suffix was originally employed for the formation of a special resultative participle in Old Russian. The past tense verb forms in Modern Russian still exhibit participial agreement pattern: they do not show any person/number agreement, as non-past forms do, but agree with the subject in number and, if the number is singular, in gender.

In Old Russian, there were four past tenses: imperfect, aorist, present perfect and past perfect. Their formation used not to be aspectually constrained, although there was a tendency to use imperfective forms in imperfect and perfective forms in aorist. ${ }^{11,12}$ Imperfect and aorist were simple (i.e. non-periphrastic) tenses, derived

10. The historical overview provided in this section is based on Avanesov (1982) and Gorškova \& Haburgaev (1981).

11. The question of how the modern tense-aspect system was formed and, especially, how the aspectual opposition was developed in Russian is a complicated and unsolved problem. Avanesov (1982) fairly says that it can only be speculated on how the aspectual opposition emerged. He, for example, hypothesizes that the aspectual differences first became apparent in the present tense and then were transferred to the past domain. As confirmed by documented evidence, at some stage the system of Old Russian was such as I present it here. The period that the relevant data come from is between the $11^{\text {th }}$ and the $14^{\text {th }}$ century.

12. Cf. the modern system of Bulgarian tense-aspect forms. 
by special inflectional morphology. They were not frequently used in Old Russian. Perfect forms were composed by combining the auxiliary verb 'to be' in the appropriate tense form with a resultative $l$-participle, which, as we have already seen, serves as the only past form in Modern Russian. The meaning of the past perfect was always to express 'past in the past', which is a common meaning of this tense in languages where it exists. The present perfect was the most commonly used 'past' form in Old Russian, just as it is in many other languages nowadays (cf. French, Dutch, etc.), especially in a colloquial, informal register. Present perfect originally had a pure resultative meaning (Gorškova \& Haburgaev 1981). In business documents dating from the 12th century (i.e., negotiations, agreements, contracts, etc.), the use of the present perfect becomes more and more frequent. At the same time, the first cases of auxiliary omission in the present perfect appear. At the beginning, it occurred most often in contexts where a full subject NP was present ${ }^{13}$ or where there was another tense form in the same sentence bearing a person agreement morphology, i.e. the cases where the person feature could be easily reconstructed.

Note that besides carrying the person agreement morphology in the present perfect, the auxiliary had yet another function: it provided the connection to the present moment. This function is familiar from the semantics of present perfect in languages like English. For Old Russian it is plausible to suggest that with the gradual loss of the auxiliary in the present perfect tense forms, the connection to the present moment that this form used to express was lost as well. Thus, what is left of the present perfect form in modern Russian is the - $l$ - participle only and it has a simple past interpretation, i.e. its essential meaning is to report on an eventuality that occurred in the past. Imagine that the same happened in English, then instead of (14a) and all the other past forms, English would only have (14b): ${ }^{14}$

(14) a. John has seen this movie.

b. John seen this movie.

Apart from the $l$-forms that used to be participles, there are no other past forms available in Modern Russian. This also explains why, although $l$-forms function as full-fledged past forms semantically, they still exhibit the participial agreement pattern: there is no person agreement feature in the past tense in Russian because the auxiliary that used to bear this feature disappeared. The development of the present perfect in Old Russian fits nicely into the general scheme of the diachronic development of this tense cross-linguistically (cf. Boogaart 1999: 134-135 and the literature cited therein), which is given in (15) below: ${ }^{15}$

13. Old Russian was a pro-drop language, modern Russian is not.

14. However, as correctly pointed out by a reviewer, the shift from the resultative/perfect to simple past in the semantics of the present perfect is observed in many languages where it cannot be connected to the auxiliary loss, e.g., Czech, German, Dutch, French, Italian, etc. Even though the auxiliary loss in Russian still might have something to do with perfect forms turning into past forms, most likely the process that was affected more straightforwardly by the auxiliary loss was the disappearance of pro-drop.

15. This is a common development path for many other languages, including many Romance and Germanic languages (see Bybee et al. 1994). 
Thus, from a diachronic perspective, the hypothesis that the original resultative meaning of the present perfect in Old Russian has transformed into the meaning of simple past is theoretically well founded.

Given that, morphologically, past tense forms in Russian are still more like participles, it might also be stipulated that the semantic relation they encode is different from the 'canonical' semantic relation that determines tense. In the tripartite system of temporal relations of a sentence, like the one of Reichenbach (1947) or Klein (1994) and the systems based on these proposals (e.g., Demirdache \& UribeEtxebarria 2000 and subsequent), the relation attributed to the tense morphology in languages is usually the one between Speech time and Reference time, as indicated in (2) above (and assuming that both variables are represented as intervals, not points of time).

For Russian, Borik $(2002,2006)$, following the model of temporal relations developed in Reinhart (1986, 2002) and Borik \& Reinhart (2004), suggested that both temporal morphology and temporal interpretation in Russian are determined by the relation between $\mathrm{E}$ (vent) time and $\mathrm{S}$ (peech) time. What I would like to propose here is a hypothesis that only past tense morphology encodes this relation, due to its hereditary participial nature. This proposal remains to be carefully evaluated and properly worked out in a formal semantic way, but an immediate advantage of it is that Russian past tense forms are predicted to have a wide range of interpretations since they encode only the E-S relation, while the position of the Reference time remains underspecified. Thus, they will have both a present and a past perfect interpretation as well as a simple past reading since in all these cases the common part of a temporal representation is the part that the Event time is located before the Speech time. ${ }^{16}$

As for the non-past forms, even though they do not exhibit any special tense morphology, as is often the case with present tense forms cross-linguistically, they are 'proper' semantic tense forms and show a person/number agreement with the subject, characteristic of finite forms. Semantically they encode the relation between the Speech time and the Reference time, a tense relation according to the scheme in (2). The hypothesis then is that different aspectual forms in this case determine whether the resulting reading would be a present, a future perfect or a simple future (or a futurate), with a simple future reading neutralizing the contrast between perfective and imperfective forms, since they both can express this reading. A perfect reading which would only be available for perfective forms in this tense, would hence be derived on the basis of different relations that would hold between the Reference time and the Event time (or another Reference time).

16. An anonymous reviewer seems to have concluded from this discussion that 'there is no $\mathrm{R}$ in Russian' and hence, 'there is no perfect'. I hope it is clear though that Reference time is something that cannot be language specific, rather model specific. Reference time (or its cognates) is part of a very influential theory of temporal relations and the fact that Reference time does not participate in a certain temporal configuration in language $\mathrm{L}$ by no means entail that there is no Reference time in a temporal system of language $\mathrm{L}$. 
However, as I already said before, the details of this proposal remain to be developed and the consequences carefully evaluated.

To sum up, we have seen in this section that Russian past tense forms of both aspects can express perfect readings. This is exactly what would be predicted by a PTS theory of the perfect, which treats perfect and viewpoint aspect (of which (im)-perfective is an example) as two independent semantic categories. Klein's (1995) theory of aspect, on the other hand, would not make this prediction, at least not straightforwardly, since the 'aspectual' relations in Klein's model encompass both perfect and (im)perfective. A more elaborate theory of relations between the two would have to be proposed given Klein's model of a sentential temporal structure or any model that is based on his proposal. As for non-past tense forms, there is an asymmetry between different aspect forms in expressing a perfect meaning and I have suggested a tentative explanation that could, in principle, capture this asymmetry.

\section{Perfect and its subtypes}

The previous section gave us a 'bird's eye view' on the relations of two categories, perfect and perfective and their possible theoretical analyses. This section will present a view from 'within' the category of perfect with the purpose to explore how different types of perfect are rendered in Russian. The discussion in this section will be mostly limited to the present perfect in English.

There are various classifications of perfect. For instance, Comrie (1976) distinguishes four different types: perfect of result, experiential perfect, perfect of persistent situation and perfect of recent past. All these meanings are exemplified in (16):

(16) a. John has gone to Africa.

result

b. John has been to Africa.

experiential

c. John has lived in Africa for three years.

persistent situation

d. John has just arrived.

recent past

The main characteristic of the first type is the persistence of the result of some past situation or an event. This effect is usually called 'relevance for the present moment'. For (16a) the relevance is expressed by the implication that John, as a result of going to Africa in the past, is still in Africa. In contrast, experiential perfect only asserts that the described type of event occurred at some point in the past. Thus, the subject of (16b), i.e, John, has experienced going to Africa at some point in life. The perfect of persistent situation in (16c) seems to be very characteristic of English and reports on a situation that started in the past and continues until the present moment. Even though in English this type of perfect is extremely common, in many other languages that do possess formal means to express perfect (including German or Dutch, the Germanic 'close relatives' of English, and also many Romance languages) this meaning is expressed by a simple present tense. Finally, the perfect of recent past exemplified by (16d) is conceptually very close to the 
perfect of result, since it still reports on a state of affairs relevant to the present moment, although the notion of relevance is couched more in temporal terms: the situation is relevant because it is very recent.

The current literature suggests different variants of the classification provided in (16). For instance, Pancheva (2003) reduces the types of perfect by one, compared to Comrie's distinctions, and proposes to distinguish the following types:

(17) a. Since 2000, Alexandra has lived in LA.

universal $(U)$

b. Alexandra has been in LA (before). experiential

c. Alexandra has (just) arrived in LA. resultative

The parallels with Comrie's classification are easy to see: while (16b) and (16c) are kept as distinct types of perfect ((17b) and (17a), respectively), the meanings exemplified in (16a) and (16d) are collapsed into one class under the common name of 'resultative' in (17c).

In other sources the classification appears even more reduced, compared to the one in (17). If experiential and resultative meanings are grouped together under the umbrella heading of 'existential' perfect (McCawley 1971, Mittwoch 1988), the minimally distinguished types of perfect become the following two:

(18) a. John has lived here for three years.

b. John has been here (before).
U-perfect

E-perfect

The distinction in (18) gives rise to a so-called universal/existential ambiguity debate (see Iatridou et al. 2001) which essentially boils down to the question of whether the two different uses of the perfect in (18) correspond to a hard-wired semantic distinction or whether they are semantically just the same perfect and the relevant distinctions between (18a) and (18b) could be pragmatically derived.

What I will illustrate in the following section is that Russian data seem to support a three-way classification of perfect types, as proposed in Pancheva (2003). In particular, it will be shown that resultative and experiential perfects are usually rendered by different aspectual forms in Russian, reflecting the difference between (17b) and (17c) above. I will propose a way to account for this difference, again in an informal way, and argue that the PTS theory of perfect, which distinguishes between perfect on the one hand and viewpoint aspect on the other, can be maintained to capture the underlying independence of the two categories.

\subsection{A Russian perspective on different perfects}

As already noted by Pancheva (2003), the literature on perfect usually focuses on the distinction between the universal and the existential varieties but rarely addresses the question of subtypes of existential perfect, which is exactly what I will focus on. I will show that empirically, there is a good reason to believe that the resultative and the experiential meanings of perfect should be distinguished at 
least on the basis of correspondences with the perfective and imperfective aspect in Russian.

Before I turn to the existential types of perfect, let me briefly comment on how the universal perfect can be expressed in Russian. In English, the universal perfect has been shown to be strictly constrained by aspect, or rather by stativity: only stative and progressive (i.e. derived stative) eventualities can give rise to a universal reading in English (cf. Iatridou et al. 2001). However, does this generalization imply that the universal perfect meaning can only be expressed by imperfective aspect?

For all the progressive perfects, the answer is without any doubt positive, but as I pointed out above, this is due to the semantic restriction posed by the progressive, not by the perfect. In other words, whatever the semantic representation of the progressive is, it also has to form part of the semantics of the imperfective as well, although not the other way around.

For those universal perfects that do not involve progressive, however, the picture is slightly more complicated because it appears that some perfective verbs in Russian can be used in the universal perfect construction. Consider the following example, where all three sentences are translational equivalents:

(19) a. I have lived here for many years.

(English)

b. Vivo aquí desde hace muchos años. live.PRES.1SG here from many years

(Spanish)

c. Ja živu/prožil zdes’ uže mnogo let. (Russian) I live.IMP.PRES/live.PF.PST here already many years

The example in (19) illustrates several important things at a time. First of all, it shows that not all languages that have a perfect express the universal meaning by means of the perfect form, as has already been pointed out above. For instance Spanish, as well as many other well studied languages, use a simple present tense to render this meaning. ${ }^{17}$ Second, (19c) illustrates one very significant fact: although there seems to be a strong tendency ${ }^{18}$ to use imperfective aspect to express the meaning of the universal perfect, some perfective verbs can still be used in this type of constructions. Two important remarks should be made with respect to the perfective verb in (19c). First of all, a critical reader who has some knowledge of Russian might immediately point out that the perfective in (19c) cannot be used without a durative temporal adverb. This is indeed so, but it has also been argued

17. A reviewer points out that it does not sound like a Spanish sentence: a Spanish uses a periphrastic construction with the verb llevar (take) to express this meaning. I would like to point out two things: first, if the llevar construction is more 'natural' for some speakers, it does not cancel the fact that the simple present still can be used (a different question is whether it sounds better or worse). Second, a simple Google search (or other native speakers for that matter) confirms that (19b) is actually fine, as it gives a lot of hits for this sentence, just as Linguee and other internet sources.

18. Ideally this kind of generalizations should be corroborated by statistical analyses, but I will have to leave this task for a future project. 
that in English the universal perfect needs obligatory adverbial support (see Iatridou et al. 2001). Secondly, there is really almost no discernable difference between a perfective and an imperfective variant of $(19 \mathrm{c}),{ }^{19}$ definitely not with respect to event completion, as can be witnessed by (20):

(20) Ja živu/prožil zdes' uže mnogo let i nikuda ne

I live.IMP.PRES/live.PF.PST here already many years and nowhere not sobirajus' uezžat.

going leave

'I have lived here for many years and am not going to move anywhere else.'

Thus, some perfective verbs can definitely be used to express the meaning of a universal perfect. On the other hand, it should be pointed out that definitely not any perfective verb can be used in this type of construction. In fact, the only type is the so-called 'perdurative' verbs, which are usually formed by means of prefix pro- with a durative meaning. These verbs have been identified as one of the two prominent classes of perfectives which provide strong empirical arguments against associating perfectivity with telicity in Russian in the strict semantic sense (see Borik \& Reinhart 2004 and Borik 2006 for extensive argumentation). It should also be pointed out that they do not provide any counterexample to the claim that the universal perfect reading is limited to stative and progressive predicates, since it can be shown that these perfectives are indeed statives (Borik 2006).

To conclude the discussion of the universal perfect, it is clear that this is a rather controversial meaning that seems to be expressed by perfect constructions less frequently than by the present tense, from a typological perspective. As for the question of how this meaning is expressed in Russian, what I have shown above is that there is at least one class of perfective verbs in Russian that can render the meaning of a universal perfect. This is why we cannot conclude that the universal perfect use leads to any strict generalizations concerning the use of perfective or imperfective aspect in expressing this meaning.

I will now turn to the difference between an experiential and a resultative perfect, both of which are instantiations of an existential perfect in English.

A hallmark of the experiential perfect is the use of indefinite adverbial expressions that 'bring out' this reading, e.g., before, 5 times, lately or ever. Consider the examples below:

(21) a. Ja i ran'še zdes' dolgo ždal avtobusa.

I and before here long wait.IPF.PST bus

'I have waited for a bus for a long time before.'

19. Although note the asymmetry: the imperfective form in (19c) is in a non-past tense whereas the perfective form is morphologically past. 
b. Ja uže pjat raz / neskol'ko raz begal marafon. I already five times / several times run.IPF.PST marathon 'I have already run a marathon five times/several times.'

c. Ty kogda-nibud' el zmeju? you ever eat.IPF.PST snake 'Have you ever eaten snake?'

d. Ja nedavno polučal britanskuju vizu, otvratitel'noe otnošenie I recently receive.IPF.PST British visa disguisting relation $\mathrm{k}$ ljudjam. to people

'I have recently applied for a British visa, they treat people horribly.'

All the examples in (21) are clear cases of an experiential perfect interpretation expressed by past imperfective forms in Russian. To make the point that imperfectivity is a necessary condition ${ }^{20}$ to render this meaning, we will now see what happens if the verb form is changed into a corresponding perfective in each particular case. As I will now show, such a change can either lead to a substantial decrease of acceptability of a sentence or to a loss of the experiential reading.

Let me start with (21a). With an imperfective verb, the sentence means the following: I have an experience of waiting for a bus for a long time here, at this bus stop, for instance. The perfective form that could be used in this example is the one with the prefix pro- and with the same durative interpretation that we have seen in (20) above. As I have already explained, these perfectives do not differ from imperfectives in terms of the eventuality type they describe: they encode stative eventualities of a specified duration. But if we substitute the verb in (21a) by a perfective form, the sentence becomes unacceptable, on the verge of being ungrammatical:

(22) \#Ja i ran'še zdes' dolgo proždal avtobusa.

I and before here long wait.PF.PST bus

Thus, in this particular case, the acceptability of a sentence seriously decreases with the change of the aspectual form.

The same can be said about the perfective variant of (21c): it is extremely difficult (if at all possible) to find a way to interpret this sentence with a perfective verb, given that the adverbial really imposes an experiential interpretation.

In the case of (21b), if the verb is changed into a perfective, the sentence is still acceptable but the interpretation changes drastically. (23), which is the version of (21b) with a perfective verb, can either mean that the speaker ran the same marathon five or several times (something that is very unlikely to be true), or that the speaker five/several times finished marathons, but then the emphasis is on the

20. Obviously, imperfectivity cannot be a sufficient condition because past imperfective forms have various interpretations, as was discussed in section 3 . 
number of times that it happens. In short, (23) does not really have an experiential perfect meaning, it just reports on how many times the speaker ran (and finished) a marathon. This is of course also an experience in life, as pretty much everything is, but in a very different, non-linguistic sense.

(23) Ja uže pjat raz / neskol'ko raz probežal marafon.

I already five times / several times run.IPF.PST marathon

'I have already run a marathon five times/several times.'

The case of (21d) is also interesting: the sentence is fully acceptable with a perfective verb, although it also loses an experiential interpretation and acquires a resultative one instead. The perfective variant of the sentence, given in (24) can only be interpreted as a statement about the speaker's recent past, not as experience:

(24) Ja nedavno polučil britanskuju vizu...

I recently receive.PF.PST British visa

'I have recently received a British visa (and am now in the possession of it).'

In this case a change in aspect leads to a change in the interpretation of a sentence and instead of an experiential perfect in (21d) we get a resultative perfect in (24). ${ }^{21}$ Thus, it seems that in Russian one can only count on an imperfective verb to express an experiential perfect meaning.

A comparison of (21d) and (24) brings out a very interesting contrast. A similar contrast can be observed in the following pairs of examples:

(25) a. Petja nedavno el ljagušku.

Peter recently eat.IPF.PST frog

'Peter has recently tried/eaten a frog.'

b. Petja nedavno s"el ljagušku.

Peter recently eat.PF.PST frog

'Peter has recently eaten a frog.' (so he is not hungry (for frogs) at this point/and got sick)

(26) a. Petja nedavno risoval pejzaž.

Peter recently paint.IPF.PST landscape

'Peter has recently painted a landscape.'

b. Petja nedavno narisoval pejzaž.

Peter recently paint.PF.PST landscape

'Peter has recently painted a landscape.' (so he is not going to paint more landscapes)

21. Perfect meanings are of course not the only ones expressed by corresponding perfective sentences, as was discussed above. 
Both (25) and (26) illustrate the same change in the interpretation as (21d) vs. (24): if a sentence with an imperfective can express the experiential perfect meaning, a corresponding one with a perfective verb form corresponds to a resultative perfect. Thus, the generalization seems to be that experiential perfect can only be expressed by imperfective aspect, whereas resulative perfect tends to be expressed by perfective forms.

From a theoretical perspective, it is important to point out that the fact that experiential and resultative meanings of perfect are rendered by different aspectual forms in Russian does not really pose a threat to a uniform semantic treatment of perfect, as might appear at first sight. The reason is that there are contexts in which the two aspects in Russian have the same semantic contribution, so there are uses where perfective and imperfective are semantically indistinguishable. One of those contexts is the general factual use of the imperfective, briefly characterized in section 2 and well described in the literature on Russian aspect (e.g., Padučeva 1996; Grønn 2003; Knyazev 2007 to mention just a few). As I already pointed out in section 2, general factual imperfectives simply refer to events that have taken place, emphasizing the mere fact that a certain event has occurred. This is one of the contexts in which morphologically imperfective predicates have a perfective semantics.

Coming back now to the discussion of the experiential vs. resultative perfect meanings and the use of (im)perfective aspect in expressing these two meanings, it should be pointed out that the experiential perfect is, in fact, a subtype of the general factual imperfective, at least in some analyses (most notably, in Grønn 2003). Hence, the semantic contribution of the imperfective aspect in the experiential perfect is, essentially, perfective, just like in all the other cases of the general factual uses of the imperfective aspect. This means that semantically, the resultative perfect and the experiential perfect meanings can be treated similarly, despite the fact that there are two different aspectual forms that are used to render these meanings in Russian. In other words, from a purely semantic perspective, the contribution of aspect in Russian in the experiential and the resultative perfect constructions can be argued to be the same.

However, the fact that there is an aspectual difference in expressing experiential and resultative perfect in Russian should also be a good indication that the two meanings should not simply be collapsed together. How precisely the relevant differences between these two uses of the perfect, possibly pragmatic in nature, should be derived is a separate and not a trivial question.

To sum up, in this section I have looked into the internal structure of perfect and have shown that a careful empirical examination of the observed correspondences between different types of perfect and the perfective/imperfective opposition can reveal some important differences between various types of perfect. However, these differences do not necessarily need to be reflected in the semantic representation of the perfect as they can be explained by the fact that they correspond exactly to those uses of morphologically imperfective aspect that are not necessarily semantically distinct from perfective. Thus, the main idea of the PTS theory of perfect, which strives to derive various uses of perfect from a uniform semantic representation, can be maintained. 


\section{Conclusion}

In this paper, I have examined three types of meaning correspondences between (im)perfective aspect in Russian and the English perfect: the ones between past tense forms of both aspects in Russian and present/past perfect forms in English, the ones between non-past tense forms of both aspects in Russian and future perfect in English and, finally, the ones between different types of (present) perfect in English and different aspect forms in Russian. I think that the past tense forms reflect the quintessential relation between perfect and (im)perfective: these are two distinct grammatical categories that can be freely combined, which means that both past perfective and past imperfective forms can express past and present perfect meanings basically without restrictions. The PTS theory of perfect can capture this result directly and straightforwardly: if perfect and (im)perfective are instantiated by different semantic operators (and syntactic categories), there should be no restrictions on combining the two. However, we have seen that the aspectual restrictions occur both in the case of non-past forms and in different types of perfect. I presented informal explanations for both restrictions, showing that they could be attributed to different factors and do not necessarily refute the PTS theory of perfect.

\section{References}

Altshuler, Daniel. 2013. There is no neutral aspect. Proceedings of Semantics and Linguistic Theory (SALT) 23: 40-61.

Avanesov, Ruben I. 1982. Istoričeskaja grammatika russkogo jazyka. Moskva: Nauka.

Boogaart, Ronny. 1999. Aspect and Temporal Ordering: A contrastive analysis of Dutch and English. The Hague: Holland Academic Graphics.

Borik, Olga. 2002. Aspect and Reference time. $\mathrm{PhD}$ thesis, Utrecht University.

Borik, Olga. 2006. Aspect and Reference time. Oxford: Oxford University Press.

Borik, Olga \& Gehrke, Berit. to appear. Imperfective past passive participles in Russian. Proceedings of Formal Description of Slavic Languages (FDSL-12). LangSci Press.

Borik, Olga \& Reinhart, Tanya. 2004. Telicity and Perfectivity: Two Independent Systems. Proceedings of the Eighth Symposium on Logic and Language (LOLA): 13-34.

Bybee, Joan, Perkins, Revere \& Pagliuca, William. 1994. The Evolution of Grammar: Tense, Aspect, and Modality in the Languages of the World. Chicago: The University of Chicago Press.

Comrie, Bernard. 1976. Aspect. An Introduction to the Study of Verbal Aspect and Related Problems. Cambridge: Cambridge University Press.

Dowty, David. 1979. Word Meaning and Montague Grammar. Dordrecht: Reidel.

Demirdache, Hamida \& Uribe-Etxebarria, Miriam. 2000. The primitives of temporal relations. In Martin, Roger, Michaels, David \& Uriagereka, Juan (eds.). Step by Step: Essays on Minimalist Syntax in Honor of Howard Lasnik, 157-186. Cambridge, MA: MIT Press. 
Iatridou, Sabine, Anagnostopoulou, Elena \& Izvorski, Roumyana. 2001. Observations about the Form and Meaning of the Perfect. In Kenstowicz, Michael (ed.). Ken Hale. A life in language, 189-238. Cambridge: The MIT Press.

Forsyth, James. 1970. A Grammar of Aspect: Usage and Meaning in the Russian verbs. Cambridge: Cambridge University Press.

Gorškova, Ksenia V. \& Haburgaev, Georgy A. 1981. Istoričeskaja grammatika russkogo jazyka. Moskva: Vysšaja škola.

Grønn, Atle. 2003. The Semantics and Pragmatics of the Russian Factual Imperfective. $\mathrm{PhD}$ Thesis, Oslo.

Kamp, Hans \& Reyle, Uwe. 1993. From Discourse to Logic; Introduction of Modeltheoretic Semantics of Natural Language, Formal Logic and Discourse Representation Theory. Dordrecht: Kluwer Academic Publishers.

Klein, Wolfgang. 1994. Time in Language. London: Routledge.

Klein, Wolfgang. 1995. A timerelational analysis of Russian aspect. Language 71(4): 669-695.

Knyazev, Juri P. 2007. Grammatičeskaja semantika. Moskva: Jazyki slavyanskix kul'tur.

McCawley, James D. 1971. Tense and time reference in English. In Fillmore, Charles J. \& Langedoen, Terence D. (eds.). Studies in Linguistic Semantics, 97-113. New York: Holt, Rinhart and Winston.

McCoard, Robert W. 1978. The English Perfect: Tense Choice and Pragmatic Inferences. Amsterdam: North-Holland.

Mittwoch, Anita. 1988. Aspects of English Aspect: On the Interaction of Perfect, Progressive and Durational Phrases. Linguistics and Philosophy 11: 203-254.

Moser, Amalia. 2003. Tense, Aspect and the Greek Perfect. In Alexiadou, Artemis, Rathert, Monica \& von Stechow, Arnim (eds.). Perfect Explorations, 235-252. Berlin: Mouton de Gruyter.

Nedjalkov, Vladimir P. 1983. Typology of resultative constructions. Amsterdam: Benjamins.

Padučeva, Elena V. 1996. Semantičeskie Issledovanija: Semantika vremeni $i$ vida v russkom jazyke. Semantika narrativa. Moskva: Jazyki russkoj kul'tury.

Pancheva, Roumyana. 2003. The Aspectual Makeup of Perfect Participles and the Interpretations of the Perfect. In Alexiadou, Artemis, Rathert, Monica \& von Stechow, Arnim (eds.). Perfect Explorations, 277-306. Berlin: Mouton de Gruyter.

Paslawska, Alla \& von Stechow, Arnim. 2003. Perfect Readings in Russian. In Alexiadou, Artemis, Rathert, Monica \& von Stechow, Arnim (eds.). Perfect Explorations, 307-362. Berlin: Mouton de Gruyter.

Reichenbach, Hans. 1947. Elements of Symbolic Logic. London: Collier-MacMillan.

Reinhart, Tanya. 1986. "States, events and reference time", Lecture given at the MIT Lexicon project.

Reinhart, Tanya. 2000. Reference time. Talk given at Language in Use Symposium, Utrecht.

Schoorlemmer, Maaike. 1995. Participial passive and aspect in Russian. $\mathrm{PhD}$ Thesis, Utrecht University.

Smith, Carlota. 1991/1997. The parameter of aspect. Dordrecht: Kluwer.

Šaxmatov, Aleksej Aleksandrovič. 1925/1941. Sintaksis russkogo jazyka. Leningrad: Učpedgiz. 
Tatevosov, Sergey. 2015. Severing imperfectivity from the verb. In Zybatow, Gerhild; Biskup, Petr; Guhl, Marcel; Hurtig, Claudia; Mueller-Reichau, Olav \& Yastrebova, Maria (eds.). Slavic Grammar from a Formal Perspective, 465-494. Frankfurt: Peter Lang.

Vinogradov, Viktor V. 1947. Russkij jazyk (grammatičeskoe učenie o slove). Moskva: Učpedgiz. 